\title{
PENGARUH GAYA KEPEMIMPINAN DAN IKLIM ORGANISASI TERHADAP SHARIA ENGAGEMENT PADA FAKULTAS EKONOMI DAN BISNIS ISLAM
}

\author{
Nuraeni Gani \\ Universitas Islam Negeri Alauddin Makassar \\ Jl. HM Yasin Limpo No.36, Romangpolong-Gowa \\ hjnuraeni.gani@gmail.com
}

\begin{abstract}
This research aims (1) to analized the influence of leadership style and organizational climate on sharia engagement at Economics and Business Faculty in Alauddin Makassar State Islamic University, (3) to analized the influence of leadership style and organizational climate on employee performance at Economics and Business Faculty in Alauddin Makassar State Islamic University. The sample uses the purposive sampling, that is, sampling based on certain considerations or criteria. All samples of 50 respondents at Economics and Business Faculty in Alauddin Makassar State Islamic University. Data analysis was done using multiple linear regression analysis, $T$ test, $F$ test and The coefficient of determination (R2). The results of an analysis of shows that (1) leadership style is a influenced to sharia engagement at Economics and Business Faculty in Alauddin Makassar State Islamic University, (2) organizational climate a influenced to sharia engagement at Economics and Business Faculty in Alauddin Makassar State Islamic University, and (3) leadership style and organizational climate a influenced to sharia engagement at Economics and Business Faculty in Alauddin Makassar State Islamic University.
\end{abstract}

Abstrak: Penelitian ini bertujuan untuk menganalisis pengaruh gaya kepemimpinan dan iklim organisasi terhadap sharia engagement baik secara simultan maupun secara parsial di Fakultas Ekonomi Dan Bisnis UIN Alauddin Makassar. Teknik pengambilan sampel yang digunakan dalam penelitian ini adalah purposive sampling. Dengan demikian maka sampel dalam penelitian ini adalah seluruh pegawai yang bekerja pada Fakultas Ekonomi Dan Bisnis UIN Alauddin Makassar. dengan jumlah sampel penelitian sebanyak 50 orang. Teknik analisis data yang digunakan dalam penelitian adalah analisa regresi linear berganda, Uji T-test, Uji F serta Uji Koefisien Determinasi (R2).. Kesimpulan yang dapat diperoleh dari hasil analisis data yang telah dilakukan adalah sebagai berikut: (1) gaya kepemimpinan berpengaruh terhadap sharia engagement di Fakultas Ekonomi Dan Bisnis UIN Alauddin Makassar.; (2) iklim organisasi berpengaruh terhadap sharia engagement di Fakultas Ekonomi Dan Bisnis UIN Alauddin Makassar. dan (3) gaya kepemimpinan dan iklim organisasi berpengaruh terhadap sharia engagement di Fakultas Ekonomi Dan Bisnis UIN Alauddin Makassar.

Kata Kunci: Gaya Kepemimpinan, Iklim Organisasi, Sharia Engagement 


\section{PENDAHULUAN}

Dalam konteks lembaga pendidikan tinggi khususnya pendidikan Islam, kehadiran sumber daya manusia yang berprinsip syariah di dalam organisasi menjadi lebih penting karena organisasi itu sendiri diciptakan oleh manusia, dan sumber daya inilah yang dapat membuat organisasi itu bisa bertahan (survive) dan sukses. Melalui usaha-usaha dan kreativitas sumber daya manusia, organisasi dapat menghasilkan suatu produk dan jasa yang berkualitas. Hal ini menggambarkan SDM sebagai faktor penting bagi keberhasilan suatu organisasi.

Universitas Islam Negeri merupakan institusi pendidikan tinggi modern yang mengkaji Islam dalam berbagai perspektif. Kenyataan ini sekaligus menempatkan UIN sebagai institusi yang menghasilkan kajian-kajian Islam kontemporer dan sarjana Muslim. Dengan demikian, pola pembelajaran yang dikembangkan di lingkungan organisasi UIN idealnya harus memadukan antara learning to know dengan learning to be, learning to do, dan learning to life together. Reposisi mengisyaratkan bahwa peran dan fungsi UIN tidak bisa dipisahkan dengan konteks ke-Indonesiaan.

Kepemimpinan dalam Islam dibangun dengan prinsip pertengahan, moderat dalam memandang persoalan. Tidak memberikan kekuasaan secara otoriter atau kebebasan secara mutlak sehingga bebas dari nilai. Ia bukan model demokrasi yang secara mutlak yang secara mutlak dapat diterapkan sepanjang sejarah dan perubahan zaman. Gaya kepemimpinan Islami merupakan proses untuk menggerakkan sekelompok orang menuju pada tujuan yang telah ditetapkan bersama dengan menolong dan memotivasi seseorang untuk bertindak sesuai dengan apa yangdiharapkan tanpa paksaan dan segala sesuatunya didasari atas ridho Allah. Setiap pemimpin bisa mempunyai gaya kepemimpinan yang berbeda antara yang satu dengan yang lain, dan tidak mesti suatu gaya kepemimpinan lebih baik atau lebih jelek dari pada gaya kepemimpinan yang lainnya. Fenomena gaya kepemimpinan menjadi sebuah masalah menarik dan berpengaruh besar dalam kehidupan berorganisasi. Gaya kepemimpinan yang diterapkan dalam suatu organisasi dapat membantu menciptakan efektivitas kerja yang positif bagi pegawai. Mengamati gaya kepemimpinan para pimpinan di Fakultas Ekonomi Dan Bisnis Uin Alauddin Makassar nampaknya telah mengintegrasikan kaidah islami dalam penerapannya sehingga menghasilkan Iklim organisasi yang islami. Namun jika mengamati beberapa pegawai staf tampaknya masih kurang bersemangat. Hal ini terlihat saat mahasiswa membutuhkan peralatan tulis atau mengurus yang lain, beberapa staf kurang bergairah dalam melayani.

Engagement mendorong individu yang terlibat di dalam organisasi membentuk suatu sistem sumber daya manusia yang mendukung aktivitas tim kerja sebagai suatu praktek yang kritis bagi organisasi (Lau, ML. and H. Ngo. 2004). Aktivitas tim mendorong kerjasama dan komunikasi di antara karyawan, pada saat yang sama aktivitas itupun mendukung penciptaan budaya kerja yang tepat. Kemudian, umpan balik atas kinerja mereka menjadi praktek yang diperlukan atasan langsung dalam meningkatkan keefektifan kerja bawahannya (Rusdianti, 2013). Konsep Shari'a berarti nilai-nilai Islam ketika diterapkan pada perekonomian bisa diterima di 
berbagai kalangan, karena bersifat universal dan tidak eksklusif (Amiri, 1997 dalam PN Pasaribu, 2011). Prinsip-prinsip etika Islam dalam pengelolaan sumber daya manusia terdiri dari tujuh prinsip yaitu persaudaraan dan kebenaran, keadilan dan kewajaran, pemenuhan kontrak, manusia yang tepat, kompensasi yang wajar, kerjasama serta kepercayaan dan kejujuran (Rice, 1999).

Tujuan penelitian yang ingin dicapai dalam penelitian ini adalah untuk menganalisis pengaruh gaya kepemimpinan dan iklim organisasi terhadap sharia engagement baik secara simultan maupun parsial pada Fakultas Ekonomi Dan Bisnis UIN Alauddin Makassar.

\section{TINJAUAN TEORETIS}

\section{Gaya Kepemimpinan}

Thoha (2004) menyatakan bahwa gaya kepemimpinan merupakan norma perilaku yang digunakan oleh seseorang pada saat orang tersebut mencoba mempengaruhi perilaku orang lain seperti yang ia lihat. Dalam hal ini usaha menyelaraskan persepsi diantara orang yang akan mempengaruhi perilaku dengan orang yang perilakunya akan dipengaruhi menjadi amat penting kedudukannya. Adapun sebagian besar teori kepemimpinan memfokuskan pada gaya kepemimpinan. Variabel ini sangat penting karena gaya kepemimpinan mencerminkan apa yang dilakukan oleh pemimpin dalam mempengaruhi pengikutnya untuk merealisasi visinya.

Gaya kepemimpinan adalah pola menyeluruh dari tindakan seorang pemimpin, baik gaya yang tampak maupun yang tidak tampak oleh bawahannya. Gaya kepemimpinan menggambarkan kombinasi yang konsisten dari falsafah, keterampilan, sifat dan sikap yang mendasari perilaku seseorang. Gaya kepemimpinan yang menunjukkan, secara langsung maupun tidak langsung, tentang keyakinan seorang pimpinan terhadap kemampuan bawahannya. Artinya, gaya kepemimpinan adalah perilaku dan strategi, sebagai hasil kombinasi dari falsafah, keterampilan, sifat, sikap yang sering diterapkan seorang pemimpin ketika ia mencoba mempengaruhi kinerja bawahannya (Thoha, 2004).

Gibson (2008) menyatakan bahwa gaya kepemimpinan adalah usaha mempengaruhi orang antar perseorangan (interpersonal) berkat proses komunikasi untuk mencapai sesuatu/beberapa tujuan. Robbins (2003) menyatakan bahwa gaya kepemimpinan adalah cara menjalankan kepemimpinan yang menurut Kenneth Blanchard terdiri dari empat gaya yaitu directing, coaching, supporting dan delegating. Untuk meningkatkan kepuasan kerja terutama efektifitas kepemimpinan maka kepemimpinan situasional menganjurkan gaya kepemimpinan yang ditampilkan oleh seorang pemimpin harus disesuaikan dengan kesiapan bawahan (Hersey dan Blanchard, 2004).

\section{Iklim Organisasi}

Muhyidin dkk (Junandi, Sri dan Maryono, 2012) menjelaskan definisi iklim organisasi adalah suasana kerja yang tercipta dari interaksi antar pribadi yang terdapat dalam suatu organisasi. Menurut Payne dan Pugh (Muhammad, 2014), iklim 
organisasi merupakan konsep perwujudan isi dan kekuatan dari nilai-nilai umum, norma- norma, tingkah laku, dan perasaan anggota terhadap suatu sistem sosial. Menurut Wirawan (2008) iklim organisasi adalah persepsi anggota organisasi (secara individual dan kelompok) dan mereka yang secara tetap berhubungan dengan organisasi.

Menurut Campbell, semakin positif iklim organisasi maka semakin produktif pula organisasi yang bersangkutan. Hal ini serupa dengan pernyataan Wayne K. Hoy dan Cecil G. Miskel yang menyebutkan ada dua tipe iklim organisasi yaitu, iklim organisasi terbuka dan iklim organisasi tertutup. Iklim organisasi terbuka memberikan dampak yang positif pada perusahaan sebab karyawan memiliki semangat kerja yang sangat tinggi, pimpinan memberikan motivasi yang lebih besar kepada karyawan untuk berprestasi, dan rasa keterpaksaan bagi karyawan dalam bekerja sangat rendah. Stringer (2002) mengemukakan bahwa terdapat lima faktor yang menyebabkan terjadinya iklim organisasi seperti diilustrasikan pada gambar. Dari kelima faktor tersebut, tiga diantaranya di bawah kontrol langsung oleh para pemimpin organisasi, yaitu strategi, praktik kepemimpinan, pengaturan organisasi. Sedangkan lingkungan eksternal dan sejarah organisasi merupakan dua faktor lainnya yang tidak dapat dikontrol oleh pemimpin organisasi.

\section{Konsep Engagement}

Engagement (keterlibatan kerja) merujuk pada keterlibatan individu dan kepuasan dengan serta antusias untuk bekerja (Harter, Schmidt, \& Hayes, 2002). Konsep ini dibangun oleh Kahn (1990), Engagement menjelaskan keterlibatan intim dengan kerangka pengalaman kerja. Ketika karyawan terlibat, emosional karyawan akan terhubung dengan orang lain dan terhadap tim kerja (Harter et al.,2002). Keterlibatan terjadi ketika karyawan tahu apa yang diharapkan, memiliki sumber daya untuk menyelesaikan pekerjaan mereka, berpartisipasi dalam peluang untuk pertumbuhan dan umpan balik, dan merasa bahwa mereka memberikan kontribusi yang signifikan bagi organisasi. Sharia engagement pertama kali dikembangkan oleh Rusdianti, (2013), yaitu keterikatan individu dalam organisasi baik secara fisik, emosional maupun spiritual yang dilandasi oleh keyakinan, keadilan/keseimbangan, kebebasan dan tanggungjawab. Sharia engagement ini berpotensi meningkatkan kinerja karyawan. Konsep syariah pada engagement dikaji melalui a). Karakteristik organisasi yang berbeda dalam hal ini adalah yang berdasarkan syariah. b) Norma sosial dan etika islam yang sudah tergeneralisasi dan menjadi acuan individu individu dalam organisasi untuk bertindak yaitu keyakinan, keadilan/keseimbangan, kebebasan dan tanggung jawab. c). Rasa kebersamaan yang diupayakan organisasi antar pimpinan, antar karyawan maupun nasabah berdasarkan prinsip syariah d). Kepercayaan masyarakat terhadap organisasi yang implikasinya nampak dari semakin banyaknya kantor cabang yang tumbuh.

\section{Pengaruh Gaya Kepemimpinan terhadap Sharia Engagement}

Employee engagement dengan perusahaan memiliki kaitan yang erat dengan hubungan karyawan dengan atasannya. Peran pemimpin adalah mempengaruhi sekelompok individu untuk mencapai tujuan bersama (Northouse, seperti dikutip oleh Batista-Taran, 2009). Seorang pemimpin yang efektif seharusnya dapat 
mempengaruhi karyawannya untuk mencapai tujuan perusahaan. Gaya kepemimpinan yang baik akan berujung pada kinerja perusahaan yang baik pula (Bass, dikutip oleh Yahaya \& Ebrahim, 2015).

\section{Pengaruh Iklim Organisasi terhadap Sharia Engagement}

Groehler \& Caruso (2005) melaporkan bahwa organisasi dengan iklim organisasi yang mampu memotivasi dan budaya kerja yang positif akan menghasilkan pegawai yang terikat secara aktif terhadap organisasi. Keterikatan pegawai secara aktif ini akan berpengaruh pada kinerja personal pegawai tersebut, dan selanjutnya akan berimbas pada kepuasan pelanggan dan kinerja organisasi. Selain itu, menurut studi yang dilakukan oleh Putter (2010), iklim organisasi berkorelasi secara signifikan dengan employee engagement, dimana ditemukan bahwa iklim organisasi yang dipersepsi menyenangkan menyebabkan employee engagement berada pada level yang lebih tinggi. Dimensi iklim organisasi yang paling tinggi memprediksi employee engagement adalah dimensi tanggung jawab. Hasil tersebut mengindikasikan bahwa employee engagement dapat distimulasi paling baik dengan cara meningkatkan persepsi terhadap tanggung jawab. Artinya memberikan pegawai otoritas, informasi, dan fasilitas yang mendukung pekerjaan, akan menjadi hal yang paling efektif untuk meningkatkan employee engagement.

\section{Pengaruh Gaya Kepemimpinan dan Iklim Organisasi terhadap Sharia Engagement}

Bass dan Riggio (2006) menjelaskan bahwa kepemimpinan yang memiliki komponen pengaruh idealis, menginspirasi melalui motivasi yang kemudian bisa menciptakan suasana kerja yang berkomitmen mencapai tujuan dan visi organisasi, pemimpin yang berperan sebagai mentor dan menghargai kebutuhan individu dirasa mampu meningkatkan employee engagement.

Faktor yang dapat memicu terciptanya employee engagement menurut McBain (2007) salah satunya yaitu, working life yang merupakan kondisi lingkungan kerja yang nyaman atau iklim organisasi yang dipersepsikan baik oleh pegawai. Menurut Robbin (Bridger, 2015) employee engagement merupakan sikap positif yang dimiliki karyawan terhadap organisasi tempat ia bekerja serta nilai-nilai yang dimiliki oleh organisasi tersebut, dalam konsep employee engagement terdapat hubungan dua arah antara pegawai dengan instansi.

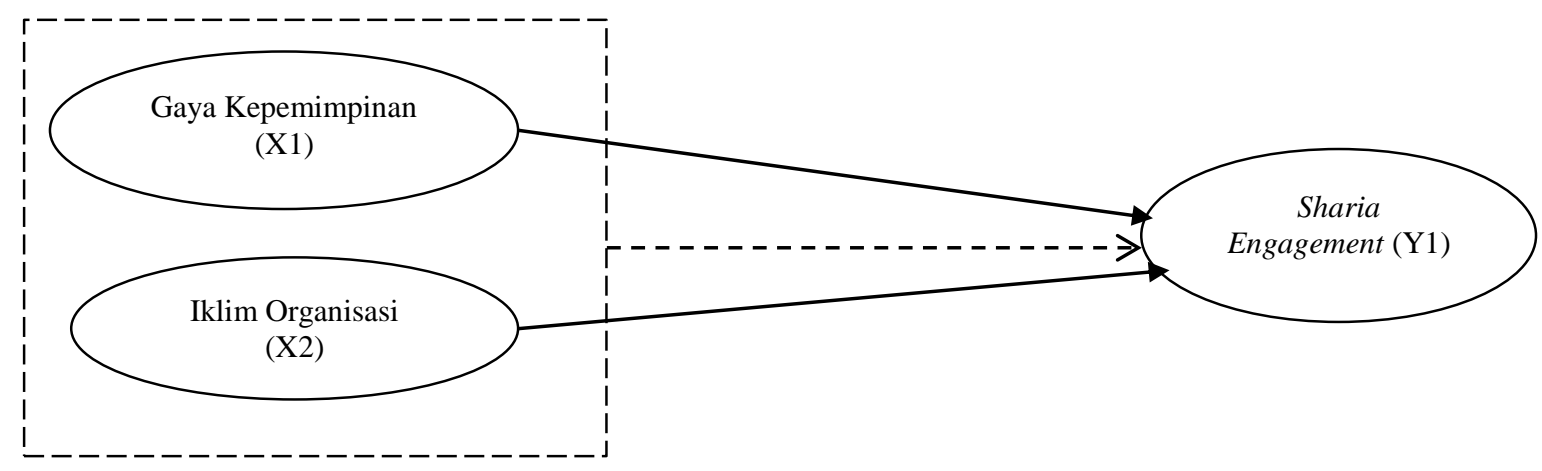

Gambar 1. Kerangka Pemikiran 


\section{METODE PENELITIAN}

Desain penelitian ini bersifat survey. Pendekatan penelitian ini adalah pendekatan kuantitatif. Jenis data dalam penelitian ini adalah data kualitatif dan data kuantitatif. Sumber data yang digunakan dalam penelitian ini adalah sumber data primer dan data sekunder. Pengumpulan data dalam penelitian ini dilakukan dengan: (1) observasi; (2) wawancara; (3) kuesioner dan (4) dokumentasi. Subjek penelitian yang akan dijadikan populasi adalah seluruh pegawai pada fakultas ekonomi perguruan tinggi islam di makassar. Teknik pengambilan sampel yang digunakan dalam penelitian ini adalah purposive sampling. Dengan demikian maka sampel dalam penelitian ini adalah seluruh pegawai yang bekerja pada Fakultas Ekonomi Dan Bisnis UIN Alauddin Makassar. dengan jumlah sampel penelitian sebanyak 50 orang. dengan jumlah populasi penelitian sebanyak 50 orang. Analisis data dilakukan dengan menggunakan analisa regresi linear berganda, Uji T-test, Uji F serta Uji Koefisien Determinasi (R2).

\section{PEMBAHASAN}

\section{Analisis Regresli Linear Berganda}

Untuk melihat pengaruh gaya kepemimpinan dan iklim organisasi terhadap sharia engagement, maka digunakan analisa regresi linear berganda. Berdasarkan hasil pengolahan data dengan bantuan program SPSS 19.0 dapat dilihat rangkuman hasil empiris penelitian sebagai berikut:

Tabel 1. Hasil Analisis Regresi

\begin{tabular}{lccccc}
\hline \multirow{2}{*}{ Model } & \multicolumn{2}{c}{$\begin{array}{l}\text { Unstandardized } \\
\text { Coefficients }\end{array}$} & $\begin{array}{c}\text { Standardized } \\
\text { Coefficients }\end{array}$ & & \\
\cline { 2 - 6 } & $\mathrm{B}$ & Std. Error & Beta & $\mathrm{t}$ & Sig. \\
\hline 1 (Constant) & 1.495 & 2.522 & & .593 & .556 \\
$\begin{array}{l}\text { Gaya kepemimpinan } \\
\text { (x1) }\end{array}$ & .496 & .075 & .664 & 6.583 & .000 \\
Iklim organisasi (x2) & .282 & .109 & & & \\
\hline
\end{tabular}

a. Dependent Variable: sharia engagement $(\mathrm{Y})$

Persamaan regresi berganda yang diperoleh dari hasil analisis yaitu: $\mathrm{Y}=1.495$ $+0.496 X_{1}+0.282 X_{2}$. Persamaan regresi tersebut mempunyai makna bahwa pengaruh gaya kepemimpinan dan iklim organisasi terhadap sharia engagement adalah positif dimana saat gaya kepemimpinan dan iklim organisasi membaik akan meningkatkan sharia engagement. Ini mengindikasikan bahwa saat gaya kepemimpinan dan iklim organisasi meningkat maka akan diikuti peningkatan sharia engagement. 


\section{Uji Parsial Dengan T-Test}

Berdasarkan Tabel 1 menunjukkan bahwa: Pertama, nilai t hitung untuk variabel gaya kepemimpinan terhadap sharia engagement diperoleh 6.583 dengan harga signifikansi 0.000 menunjukkan bahwa nilai $t$ yang diperoleh tersebut signifikan karena harga signifikansi yang diperoleh kurang dari 0.05. Karena nilai $t$ hitung 6.583 lebih besar dari t tabel 1.675 maka hipotesis nol (H0) ditolak dan hipotesis satu (H1) diterima, sehingga hal ini berarti bahwa variabel gaya kepemimpinan $\left(\mathrm{X}_{1}\right)$ memiliki pengaruh yang signifikan terhadap sharia engagement $(\mathrm{Y})$.

Kedua, nilai thitung untuk variabel iklim organisasi terhadap sharia engagement diperoleh 2.587 dengan harga signifikansi 0.013 menunjukkan bahwa nilai t yang diperoleh tersebut signifikan karena harga signifikansi yang diperoleh kurang dari 0.05. Karena nilai t hitung 2.587 lebih besar dari t tabel 1.675 maka hipotesis nol (H0) ditolak dan hipotesis dua (H2) diterima, sehingga hal ini berarti bahwa variabel iklim organisasi $\left(\mathrm{X}_{2}\right)$ memiliki pengaruh yang signifikan terhadap sharia engagement $(\mathrm{Y})$.

\section{Uji Simultan Dengan F-Test (Anova $\left.{ }^{b}\right)$}

Uji F untuk menentukan apakah secara serentak/bersama-sama variabel independen mampu menjelaskan variabel dependen dengan baik atau apakah variabel independen secara bersama-sama mempunyai pengaruh yang signifikan terhadap variabel dependen. Pada tabel Anova dapat dilihat pengaruh variabel independen gaya kepemimpinan dan iklim organisasi terhadap variabel dependen sharia engagement di Fakultas Ekonomi Dan Bisnis UIN Alauddin Makassar secara simultan/bersama. Dimana setelah dilakukan penganalisaan dengan SPSS 19.0 maka didapat output sebagai berikut:

Tabel 2. Output Uji F

\begin{tabular}{llccccc}
\hline Model & $\begin{array}{c}\text { Sum of } \\
\text { Squares }\end{array}$ & df & Mean Square & F & Sig. \\
\hline 1 & Regression & 51.465 & 2 & 25.733 & 25.757 & $.000^{\mathrm{a}}$ \\
& Residual & 46.955 & 47 & .999 & & \\
Total & 98.420 & 49 & & & \\
\hline
\end{tabular}

a. Predictors: (Constant), gaya kepemimpinan (x1), iklim organisasi (x2)

b. Dependent Variable: sharia engagement (Y)

Berdasarkan Tabel 2 menunjukkan bahwa hasil pengujian hipotesis dengan perhitungan uji $\mathrm{F}$ menggunakan program SPSS for Windows release 19.00 diperoleh $\mathrm{F}$ hitung = 25.757 yang lebih besar dari $\mathrm{F}$ tabel sebesar 3.18 dan dengan harga signifikansi sebesar 0.000. Karena harga signifikansi kurang dari 0.05, menunjukkan bahwa nilai F hitung yang diperoleh tersebut signifikan. Dengan demikian menunjukkan bahwa secara bersama-sama terdapat pengaruh yang signifikan gaya kepemimpinan dan iklim organisasi terhadap sharia engagement di Fakultas Ekonomi Dan Bisnis UIN Alauddin Makassar.

\section{Uji Koefisien Determinasi (R Square)}


Derajat pengaruh antar gaya kepemimpinan dan iklim organisasi terhadap sharia engagement secara bersama-sama atau secara simultan dapat diketahui dari harga korelasi secara simultan atau R sebagaimana pada Tabel 3 berikut.

Tabel 3 Output Korelasi Simultan

\begin{tabular}{lllll}
\hline Model & R & \multicolumn{2}{c}{ R Square Adjusted R Square } & $\begin{array}{c}\text { Std. Error of the } \\
\text { Estimate }\end{array}$ \\
\hline 1 & $.723^{\mathrm{a}}$ & .523 & .503 & 1.000 \\
\hline
\end{tabular}

a. Predictors: (Constant), gaya kepemimpinan $(x 1)$, iklim organisasi $(\mathrm{x} 2)$

Berdasarkan hasil perhitungan diperoleh harga koefisien korelasi secara simultan sebesar 0.723 dengan nilai $\mathrm{R}$ square sebesar 0.523 . Ini mengindikasikan bahwa kuat pengaruh secara bersama-sama variabel gaya kepemimpinan dan iklim organisasi terhadap sharia engagement masuk dalam kategori sedang. Besarnya pengaruh gaya kepemimpinan dan iklim organisasi dapat diketahui dari harga koefisien determinasi simultan $\left(\mathrm{R}^{2}\right)$ yang menunjukkan secara bersama-sama gaya kepemimpinan dan iklim organisasi memiliki pengaruh sebesar $52.3 \%$ terhadap sharia engagement. Sedangkan selebihnya sebesar $47.7 \%$ adalah pengaruh faktor lain yang tidak dimasukkan ke dalam model ini.

\section{PEMBAHASAN}

\section{Pengaruh Gaya Kepemimpinan terhadap Sharia Engagement}

Penelitian ini menunjukkan bahwa adanya pengaruh positif dan signifikan secara parsial gaya kepemimpinan terhadap sharia engagement. Hal ini terlihar dari hasil uji $\mathrm{t}$ anova didapatkan hasil gaya kepemimpinan berpengaruh positif dan signifikan terhadap sharia engagement, hal ini terlihat dari nilai thitung untuk variabel gaya kepemimpinan terhadap sharia engagement diperoleh 6.583 dengan harga signifikansi 0.000 menunjukkan bahwa nilai $\mathrm{t}$ yang diperoleh tersebut signifikan karena harga signifikansi yang diperoleh kurang dari 0.05 .

Hasil penelitian ini sejalan dengan pernyataan bahwa employee engagement dengan perusahaan memiliki kaitan yang erat dengan hubungan karyawan dengan atasannya. Peran pemimpin adalah mempengaruhi sekelompok individu untuk mencapai tujuan bersama (Northouse, seperti dikutip oleh Batista-Taran, 2009: 16). Seorang pemimpin yang efektif seharusnya dapat mempengaruhi karyawannya untuk mencapai tujuan perusahaan. Gaya kepemimpinan yang baik akan berujung pada kinerja perusahaan yang baik pula (Bass, dikutip oleh Yahaya \& Ebrahim, 2015: 190). Bass dan Riggio (2006) menjelaskan bahwa kepemimpinan yang memiliki komponen pengaruh idealis, menginspirasi melalui motivasi yang kemudian bisa menciptakan suasana kerja yang berkomitmen mencapai tujuan dan visi organisasi, pemimpin yang berperan sebagai mentor dan menghargai kebutuhan individu dirasa mampu meningkatkan employee engagement. 
Implikasi manajerial pada pengaruh gaya kepemimpinan terhadap sharia engagement adalah keterikatan individu dalam organisasi baik secara fisik, emosional maupun spiritual yang dilandasi oleh keyakinan, keadilan/keseimbangan, kebebasan dan tanggungjawab yaitu mampu meningkatkan gaya kepemimpinan dengan cara mengarahkan (directing), yaitu memberikan instruksi tertentu dan mengawasi dari dekat, kemudian melatih (coaching), yaitu menerangkan instruksinya, mengundang pendapat dan memberikan bimbingan, selanjutnya mendukung (supporting), yaitu membagi proses pembuatan keputusan dan pemecahan masalah dengan anak buahnya dalam menyelesaikan tugas, kemudian mendelegasikan (delegating), yaitu memberikan tanggung jawab dalam pembuatan keputusan dan pemecahan masalah kepada bawahannya dan terakhir konsultasi (consult), yaitu pemimpin menentukan masalah, mengusulkan alternative tindakan dan meminta saran mengenai tindakan yang akan dilakukan.

\section{Pengaruh Iklim Organisasi terhadap Sharia Engagement}

Penelitian ini menunjukkan bahwa adanya pengaruh positif dan signifikan secara parsial iklim organisasi terhadap sharia engagement. Hal ini terlihar dari hasil uji $\mathrm{t}$ anova didapatkan hasil iklim organisasi berpengaruh positif dan signifikan terhadap sharia engagement, hal ini terlihat dari nilai t hitung untuk variabel iklim organisasi terhadap sharia engagement diperoleh 2.587 dengan harga signifikansi 0.013 menunjukkan bahwa nilai $\mathrm{t}$ yang diperoleh tersebut signifikan karena harga signifikansi yang diperoleh kurang dari 0.05.

Hasil penelitian ini sejalan dengan pernyataan Groehler \& Caruso (2005) melaporkan bahwa organisasi dengan iklim organisasi yang mampu memotivasi dan budaya kerja yang positif akan menghasilkan pegawai yang terikat secara aktif terhadap organisasi. Keterikatan pegawai secara aktif ini akan berpengaruh pada kinerja personal pegawai tersebut, dan selanjutnya akan berimbas pada kepuasan pelanggan dan kinerja organisasi. Selain itu, menurut studi yang dilakukan oleh Putter (2010), iklim organisasi berkorelasi secara signifikan dengan employee engagement, dimana ditemukan bahwa iklim organisasi yang dipersepsi menyenangkan menyebabkan employee engagement berada pada level yang lebih tinggi. Dimensi iklim organisasi yang paling tinggi memprediksi employee engagement adalah dimensi tanggung jawab. Hasil tersebut mengindikasikan bahwa employee engagement dapat distimulasi paling baik dengan cara meningkatkan persepsi terhadap tanggung jawab. Artinya memberikan pegawai otoritas, informasi, dan fasilitas yang mendukung pekerjaan, akan menjadi hal yang paling efektif untuk meningkatkan employee engagement. Faktor yang dapat memicu terciptanya employee engagement menurut McBain (2007) salah satunya yaitu, working life yang merupakan kondisi lingkungan kerja yang nyaman atau iklim organisasi yang dipersepsikan baik oleh pegawai. Menurut Robbin (Bridger, 2015) employee engagement merupakan sikap positif yang dimiliki karyawan terhadap organisasi tempat ia bekerja serta nilai-nilai yang dimiliki oleh organisasi tersebut, dalam konsep employee engagement terdapat hubungan dua arah antara pegawai dengan instansi.

Implikasi manajerial pada pengaruh iklim organisasi terhadap sharia engagement adalah keterikatan individu dalam organisasi baik secara fisik, emosional 
maupun spiritual yang dilandasi oleh keyakinan, keadilan/keseimbangan, kebebasan dan tanggungjawab yaitu mampu meningkatkan iklim organisasi dengan lingkungan eksternal, yaitu lingkungan eksternal organisasi mempengaruhi perilaku pegawai, kemudian strategi organisasi, yaitu strategi mempengaruhi iklim organisasi secara tidak langsung, selanjutnya pengaturan organisasi, yaitu pengaturan organisasi mempunyai pengaruh paling kuat terhadap iklim organisasi, kemudian kekuatan sejarah, yaitu semakin tua umur suatu organisasi semakin kuat pengaruh kekuatan sejarahnya dan terakhir kepemimpinan, yaitu perilaku pemimpin mempengaruhi iklim organisasi yang kemudian mendorong motivasi pegawai.

Pengaruh Gaya Kepemimpinan dan Iklim Organisasi terhadap Sharia Engagement

Dari hasil uji F anova didapatkan hasil variabel gaya kepemimpinan dan iklim organisasi berpengaruh positif dan signifikan secara simultan terhadap sharia engagement. hal ini terlihat dari Nilai $\mathrm{F}$ hitung untuk variabel gaya kepemimpinan dan iklim organisasi terhadap sharia engagement diperoleh 25.757 dengan harga signifikansi 0.000 menunjukkan bahwa nilai $\mathrm{F}$ yang diperoleh tersebut signifikan karena harga signifikansi yang diperoleh kurang dari 0.05 .

Berdasarkan hasil perhitungan diperoleh harga koefisien korelasi secara simultan sebesar 0.723 dengan nilai $\mathrm{R}$ square sebesar 0.523 . Ini mengindikasikan bahwa kuat pengaruh secara bersama-sama variabel gaya kepemimpinan dan iklim organisasi terhadap sharia engagement masuk dalam kategori sedang. Besarnya pengaruh gaya kepemimpinan dan iklim organisasi dapat diketahui dari harga koefisien determinasi simultan $\left(\mathrm{R}^{2}\right)$ yang menunjukkan secara bersama-sama gaya kepemimpinan dan iklim organisasi memiliki pengaruh sebesar $52.3 \%$ terhadap sharia engagement. Sedangkan selebihnya sebesar $47.7 \%$ adalah pengaruh faktor lain yang tidak dimasukkan ke dalam penelitian ini. Artinya bahwa, besarnya pengaruh gaya kepemimpinan dan iklim organisasi dalam kategori sedang dalam mempengaruhi sharia engagement.

\section{PENUTUP}

Kesimpulan yang dapat diperoleh dari hasil analisis data yang telah dilakukan adalah sebagai berikut: (1) gaya kepemimpinan berpengaruh positif dan signifikan terhadap sharia engagement di Fakultas Ekonomi Dan Bisnis UIN Alauddin Makassar. Sehingga saat gaya kepemimpinan membaik akan diikuti dengan peningkatan sharia engangement .Dengan demikian, dapat disimpulkan bahwa gaya kepemimpinan akan mempengaruhi sharia engagement; (2) iklim organisasi berpengaruh positif dan signifikan terhadap sharia engagement di Fakultas Ekonomi Dan Bisnis UIN Alauddin Makassar sehingga saat iklim orgnaisasi membaik akan diikuti peningkatn sharia engangement. Dengan demikian, dapat disimpulkan bahwa iklim organisasi akan mempengaruhi sharia engagement . 


\section{DAFTAR PUSTAKA}

Awaluddin, Murtiadi. "Penguatan Peran Lingkungan Kerja dan Budaya Organisasi dalam Mengoptimalkan Kinerja Dosen Universitas Islam Negeri Alauddin Makassar melalui Kepuasan Kerja." Jurnal Minds: Manajemen Ide dan Inspirasi 5, no. 1 (2018): 53-67.

Awaluddin, Murtiadi. "Penguatan Peran Perguruan Tinggi Islam Dalam Mendorong Pengembangan Lembaga Keuangan Syariah di Indonesia." Jurnal Iqtisaduna 4, no. 2 (2018): 238-249.

Bass, M. Bernard dan Riggio, E. Ronald. 2006. Transformational Leadership. Second Edition. New Jersey: Lawrence Erlbaum Associates. Publishers

Batista-Taran, L. C., Shuck, M. B., Gutierrez, C. C., \& Baralt, S. 2009. The role of leadership style in employee engagement. In M. S. Plakhotnik, S. M. Nielsen, \& D. M. Pane (Eds.), Proceedings of the Eighth Annual College of Education \& GSN Research Conference (pp. 15-20). Miami: Florida International University

Bridger, E. 2015. Employee Engagement. United States: Kogan Page

Gibson, J. L., Ivancevich, J. M., dan Donnelly, J. H., 2008, Organisasi, Perilaku, Struktur, dan Proses, Jakarta : Binapura Aksara Publisher.

Groehler, L. and Caruso, K. 2005. Using HR Metrics to Understand the Drivers of Employee Engagement. [online] viapeople. Available at: http:/ / www.viapeople.com/HRMetric.pdf

Harter, J. K., Schmidt, F. L., \& Hayes, T. L. 2002. Business-unit-level relationship between employee satisfaction employee engagement, and business outcomes: A meta-analysis. Journal of Applied Psychology, 87, 268-279

Hersey, Paul dan Blanchard, Kenneth. H. 2004. Management of Organizational Behavior: Utilizing. Human Resources, Prentice Hall, New Jersey

Junandi, Sri; dan Maryono. 2012. Pengaruh Iklim Organisasi Terhadap KinerjaPustakawan Universitas Gadjah Mada. Diterbitkan dalam "Sangkakala" Ed.12 Th. 2012

Kahn, W.A. 1990. Psychological Conditions of Personal Engagement and Disengagement at Work. Academy of Management Journal, Vol. 33, No. 4, 692 $-724$

Lau, ML. and H. Ngo. 2004. The HR System,Organizational Culture and Product Innovation. International Business Review

McBain, R. 2007. The Practice of Engagement: Research into Current Employee Engagement Practice. Strategic HR Review, 6, 16-19.

Muhammad, Siswanto, 2014, sikap kerja karyawan perbankan syariah berdasarkan karakteristik biografis, Malang

Northouse, P. G. 2004. Leadership theory and practice (3rd ed.). Thousand Oaks, CA: Sage

PN Pasaribu, 2011, Model SDM Perbankan Syariah berbasis nilai, repository,mb ipb.ac.id

Putter, L. 2010. Organizatinal Climate and Performance, Thesis, Delft: DelftUniversity of Technology 
Rice G. 1999. Islamic Ethics and the Implications for Business. Journal for Business Ethic

Robbins, S. P. 2003. Organizational behavior (10th ed). New Jersey : Prentice Hall

Rusdianti, E. 2013. Membangun Pertautan Syariah Kaitannya Dengan Peningkatan Kinerja Karyawan. Disertasi, Universitas Diponegoro, Semarang

Stringer, R. 2002. Leadership and Organizational Climate. New Jersey: Prentice Hall.

Thoha ,Miftah, 2004, Kepemimpinan Dalam Manajemen, Penerbit Rajawali pers.Jakarta

Wirawan. 2008. Budaya dan Iklim Organisasi: Teori Aplikasi dan Penelitian. Jakarta: Salemba Empat. 